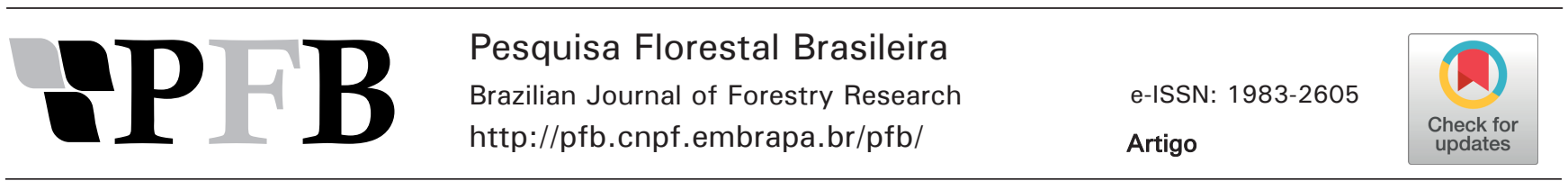

\title{
Shoot multiplication of two Sequoia sempervirens genotypes with addition of small concentrations of kinetin
}

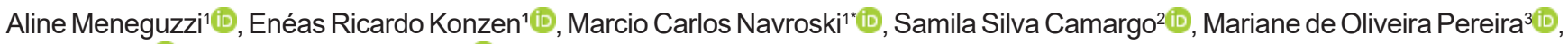 \\ Leo Rufato ${ }^{2}$ (iD, Queli Cristina Lovatel'10 \\ ${ }^{1}$ Universidade do Estado de Santa Catarina, Departamento de Engenharia Florestal, Av. Luiz de Camões, 2090, CEP 88520-000, Lages, SC, Brazil \\ 2Universidade do Estado de Santa Catarina, Departamento de Agronomia, Av. Luiz de Camões, 2090, CEP 88520-000, Lages, SC, Brazil \\ ${ }^{3}$ Universidade Federal do Paraná, Departamento de Engenharia Florestal, Av. Prefeito Lothário Meissner, 632, CEP 80210-170, Curitiba, PR, Brazil
}

"Corresponding author:

marcio.navroski@udesc.br

Index terms:

Micropropagation

Cytokinins

Callogenesis

Termos para indexação:

Micropropagação

Citocininas

Calogênese

Histórico do artigo:

Received in 05/12/2017

Accepted in 29/03/2019

Published in 23/12/2019

\begin{abstract}
Sequoia sempervirens (D. Don) Endl. is a conifer which produces highquality wood with potential industrial applications. However, the species shows low germination rates. This study was devoted to optimizing a protocol for shoot multiplication of $S$. sempervirens through micropropagation. Two genotypes, adapted to southern Brazil, constituted the source of explants for consecutive experiments aiming in vitro multiplication. We used the traditional MS (Murashige \& Skoog) culture medium at $50 \%$ of its original concentration, supplemented with plant growth regulators under two approaches. For multiplication we combined $\alpha$-naphtalene acetic acid (NAA) and 6-benzilaminopurine (BAP) at distinct concentrations. In the second experiment, we tested concentrations of three cytokinins types (BAP, kinetin and 2-isopentheiladenine ). NAA at $0.1 \mathrm{mg} \mathrm{L}^{-1}$ enabled the production of shoots with higher mean length for the main branch. The use of kinetin in low concentrations provided the best performance for shoot multiplication, differing between two genotypes. We outline a recommendation of the most suitable plant growth regulators and their concentration for shoot multiplication of S. sempervirens, which might assist further work aiming at adventitious rooting and acclimatization.
\end{abstract}

\section{Micropropagação de dois genótipos de Sequoia sempervirens com adição de pequenas concentrações de cinetina}

Resumo - Sequoia sempervirens (D. Don) Endl. é uma conífera que produz madeira de elevada qualidade, com potencial de aplicação na indústria. No entanto, a espécie exibe baixas taxas de germinação. Este estudo foi dedicado à otimizar um protocolo para a multiplicação de brotos de $S$. sempervirens, através da micropropagação. Dois genótipos, adaptados ao Sul do Brasil, foram a fonte de explantes para o estudo da multiplicação in vitro. Utilizou-se o meio de cultura MS (Murashige Skoog) (50\% de sua concentração original) complementado com reguladores de crescimento sob duas abordagens. Para a multiplicação, foram combinados ácido $\alpha$-naftaleno acético (ANA) e 6-benzilaminopurina (BAP), em concentrações distintas. No segundo experimento foram testadas, separadamente, três concentrações de cintinas (BAP, cinetina e 2-isopentenladenina). ANA, na concentração $0,1 \mathrm{mg} \mathrm{L}^{-1}$, permitiu a produção de brotos com maior comprimento médio do ramo principal. $\mathrm{O}$ uso de cinetina, em baixas concentrações, proporcionou o melhor desempenho para a multiplicação de brotos, mas com desempenhos distintos, de acordo com o genótipo. Descrevemos uma recomendação dos reguladores de crescimento de plantas mais adequados e suas concentrações para a multiplicação de brotos de $S$. sempervirens, o que pode auxiliar trabalhos voltados para enraizamento e aclimatização adventícia. 


\section{Introduction}

Sequoia sempervirens (Lamb. ex. Don) Endl., commonly referred as sequoia, is a conifer which occurs naturally in Western North America, especially in California, USA. It is known for its high-quality wood production. It has been introduced to other continents, where it has been gradually domesticated (Liu et al., 2006). In Brazil, it has been cultivated for reforestation and ornamentation. Southern Brazil has proper climate for development of this species especially at areas of high altitude from northeastern region of Rio Grande do Sul state and part of Santa Catarina state (Navroski et al., 2015).

Due to specific environmental conditions, such as climate and soil, silviculture of $S$. sempervirens in Southern Brazil requires the selection of genetic materials adapted to such conditions (Navroski et al., 2015). More importantly, growing high-quality seedlings is a fundamental step toward $S$. sempervirens plantation. Sequoia propagation via seeds has a major issue associated to its low germination rate (average of $10 \%)$. Moreover, it has been recommended to collect seeds from trees that are at least 250 years old as plant viability is normally low from propagules obtained from young trees (Olson et al., 1990).

Therefore, clonal propagation of $S$. sempervirens is a suitable alternative for maximizing the production of cuttings from selected materials. More specifically, the micropropagation strategy enables the production of a high number of seedlings genetically identical to the selected matrices (Hartmann et al., 2011; Xavier et al., 2013; Brondani et al., 2017). However, it requires the culture medium optimization for appropriate concentration of plant growth regulators, especially a balance between cytokinins and auxins. Culture medium supplementation with plant growth regulators has been proven to increase the number of shoots emitted per propagule, as well as their length in Pinus (Rocha et al., 2009). However, little information is available on $S$. sempervirens micropropagation. In general, most of the researches have been dedicated to optimize protocols for somatic embryogenesis (Liu et al., 2006), cryopreservation (Ozudogru et al., 2011; Halmagyi et al., 2017), the epigenetic implications of cultured shoots (Huang et al., 2012) and the effect of plant tissues age (juvenility) on adventitious rooting performance (Blažková et al., 1997).
Our study aimed at finding an adequate concentration of plant growth regulators for in vitro multiplication of $S$. sempervirens clones. In the first experiment, we tested the effect of cytokinin 6-benzilaminopurine (BAP) and auxin $\alpha$-naphthalene acetic acid added to the traditionally used MS (Murashige and Skoog) culture medium. After, we compared the effects of the culture medium supplementation with three distinct cytokinin types (BAP; 2-isopentheiladenine; and kinetin), at distinct concentrations.

\section{Material and methods}

\section{Genotype used for the experiments}

The genetic material was obtained from two adult trees, nearly 40 years old, identified as A140 and A228 and located at the National Forest of São Francisco de Paula (29 25'22" S and 50'23'11' W), Rio Grande do Sul State, southern Brazil.

Cuttings were collected at $30 \mathrm{~cm}$ height from the ground and transported in a thermal box, containing water, to a greenhouse located at Santa Catarina State University, at Lages, SC. The cuttings were prepared to $10 \mathrm{~cm}$ in length, containing one pair of leaves with $50 \%$ of their original leaf area and treated with $6.000 \mathrm{mg} \mathrm{L}^{-1}$ of IBA (indole-3-butyric acid). Cuttings were then planted in growth tubes $\left(180 \mathrm{~cm}^{3}\right)$ containing vermiculite and commercial substrate medium $(1: 1, \mathrm{v} / \mathrm{v})$ and placed in a greenhouse with controlled temperature $\left(25 \pm 5{ }^{\circ} \mathrm{C}\right)$ and humidity $(>70 \%)$.

After five months, rooted plants were acclimated in a shade house ( $33 \%$ shade), for 30 days and then transferred to a conventional greenhouse for more 30 days, both stages without temperature or humidity control. After this period, plants with approximately $20 \mathrm{~cm}$ height were transferred to recipients (capacity of 5 L) filled with commercial substrate and vermiculite medium $(1: 1, \mathrm{v} / \mathrm{v})$. After 15 days of adaptation, plants were pruned to $10 \mathrm{~cm}( \pm 2 \mathrm{~cm})$ height, constituting the ministumps to establish a clonal mini-garden. The minigarden was regularly fertilized with a solution composed by $1 \mathrm{~g} \mathrm{~L}^{-1}$ of Forth ${ }^{\circledR}\left(10 \% \mathrm{~N}, 42 \% \mathrm{P}_{2} \mathrm{O}_{5}, 10 \% \mathrm{~K}_{2} \mathrm{O}, 0.6 \%\right.$ $\mathrm{Mg}, 0.1 \% \mathrm{Fe}$ and $0.02 \% \mathrm{Br}$ ). Fertigation was performed twice a week. Each mini-stump received $50 \mathrm{~mL}$ of fertilizer solution at ratio $1.5 \mathrm{~g} \mathrm{~L}^{-1}$. Explants for in vitro establishment were obtained from the clonal minigarden. 


\section{In vitro establishment stage}

In vitro experiments started with an establishment stage, consisting on the explants inoculation in the traditional MS culture medium (Murashige \& Skoog, 1962). The explants were collected from the minigarden as nodal segments of approximately $1 \mathrm{~cm}$ length. Prior to inoculation, explants were surface sterilized with active chlorine, using a commercial sodium hypochlorite formula ( $\mathrm{NaClO}, 2 \%$ active chlorine). The explants were then washed in sterilized and deionized water within a flow chamber, and immediately inoculated in test tubes containing $10 \mathrm{~mL}$ of solidified culture medium. The explants remained 60 days in a growth chamber with temperature at $25 \pm 2{ }^{\circ} \mathrm{C}$ and photoperiod of $16 \mathrm{~h}$, and after that they were evaluated according to their survival, contamination and oxidation. Established explants were used in the next stage, in vitro multiplication.

\section{Experiment 1}

We used stem micro-cuttings from the genotype A228, previously established in in vitro conditions, with an average of $1 \pm 0.2 \mathrm{~cm}$ in length. We used 6-benzilaminopurine (BAP) and $\alpha$-naphthalene acetic acid (NAA) at $0,0.1,0.5$ and $1 \mathrm{mg} \mathrm{L}^{-1}$, as distinct treatments. The experiment was conducted in completely randomized design, in factorial arrangement $(4 \times 4)$, with five replicates of three explants each.

\section{Experiment 2}

We used micro-cuttings obtained from in vitro conditions, with $1 \pm 0.2 \mathrm{~cm}$ length. The treatments were arranged with the combination of two clones (A228 and A140) with three distinct cytokinins (BAP; 2-isopentheiladenine and kinetin), all at 0, 0.5, 1, 2 and $4 \mathrm{mg} \mathrm{L}^{-1}$. The experiment was performed in a completely randomized design in factorial arrangement $(2 \times 3 \times 5)$, with six replicates of three explants each.

\section{Preparation of the culture medium for both experiments and inoculation}

For the establishment stage, we used the MS culture medium (Murashige \& Skoog, 1962) prepared at full concentration of each nutrient and supplemented with $100 \mathrm{mg} \mathrm{L}^{-1}$ of myo-inositol, $30 \mathrm{~g} \mathrm{~L}^{-1}$ of sucrose and $60 \mathrm{~g} \mathrm{~L}^{-1}$ of agar. In the multiplication stage, the culture medium was prepared at $50 \%$ of the original MS concentration of nutrients and vitamins. The culture medium $\mathrm{pH}$ was adjusted to 5.8 before adding agar and it was distributed to glass flasks (capacity of $250 \mathrm{~mL}$ ) in a flow chamber. Each flask received $30 \mathrm{~mL}$ of culture medium. All materials were sterilized for $20 \mathrm{~min}$ at $121{ }^{\circ} \mathrm{C}$ and $1 \mathrm{~kg} \mathrm{~cm}^{-2}$.

The excision of micro-cuttings from established explants and inoculation in flasks prepared according to each treatment was carried out in the flow chamber. After inoculation, micro-cuttings were maintained in a growth room with controlled temperature at $25 \pm 2{ }^{\circ} \mathrm{C}$ and photoperiod of $16 \mathrm{~h}$. The light intensity was $42 \mu \mathrm{mol} \mathrm{m}{ }^{-2} \mathrm{~s}^{-1}$.

\section{Response variables and statistical analysis}

After 60 days of cultivation, we measured the total length of the main branch and we determined the average number of shoots per explant, the average length of shoots, the number of needles per explant and the presence of calluses. The data were verified for their adherence to normality and homogeneity of variances. After, we carried out analysis of variance (ANOVA). If the treatments were significantly different through $F$ test $(p<0.05)$, mean comparisons were conducted with Tukey's test $(\mathrm{p}<0.05)$ for qualitative variables and through regression analysis $(\mathrm{p}<0.05)$ for quantitative variables. Statistical analyses were carried out using the package SISVAR (Ferreira, 2011). Graphic representation was performed with spreadsheet software and surface response graphics were designed with Statistica ${ }^{\circledR} 6.0$ (Statistica, 2019). Variables expressed as percentages were transformed with $\operatorname{arc} \operatorname{sen} \sqrt{ }(x / 100)$, where $x$ is the percentage obtained for each variable.

\section{Results}

We detected interaction $(\mathrm{p}<0.05)$ between the two growth regulators for the average number of shoots and the average number of needles when using distinct concentrations of $\alpha$-naphtalene acetic acid (NAA) and 6-benzilaminopurine (BAP) (Figure 1). Although, the length of the main stem differed for both BAP and NAA separately $(p<0.05)$ the average length of the shoots showed difference only when using NAA.

The combination of $0.5 \mathrm{mg} \mathrm{L}^{-1} \mathrm{NAA}$ with $0.1 \mathrm{mg} \mathrm{L}^{-1}$ BAP resulted in the highest number of shoots per explant (Figure 1a). The average number of needles was higher when $0.5 \mathrm{mg} \mathrm{L}^{-1} \mathrm{NAA}$ was combined with $0.5 \mathrm{mg} \mathrm{L}^{-1}$ BAP. However, it showed no difference when increasing BAP to $1.0 \mathrm{mg} \mathrm{L}^{-1}$ (Figure $1 \mathrm{~b}$ ). 
The mean length of the main branch showed a negative quadratic behavior (Figure 2a). The highest average values were measured from $0.1 \mathrm{mg} \mathrm{L}^{-1} \mathrm{NAA}$ and from $0.1 \mathrm{mg} \mathrm{L}^{-1}$ BAP medium, with 9.78 and $8.42 \mathrm{~cm}$, respectively. Conversely, the lowest lengths were measured from the micro-cuttings grown in medium containing $1 \mathrm{mg} \mathrm{L}^{-1}$ of both regulators. Better performance of the shoots length was also observed when $0.1 \mathrm{mg} \mathrm{L}^{-1}$ of NAA was used.
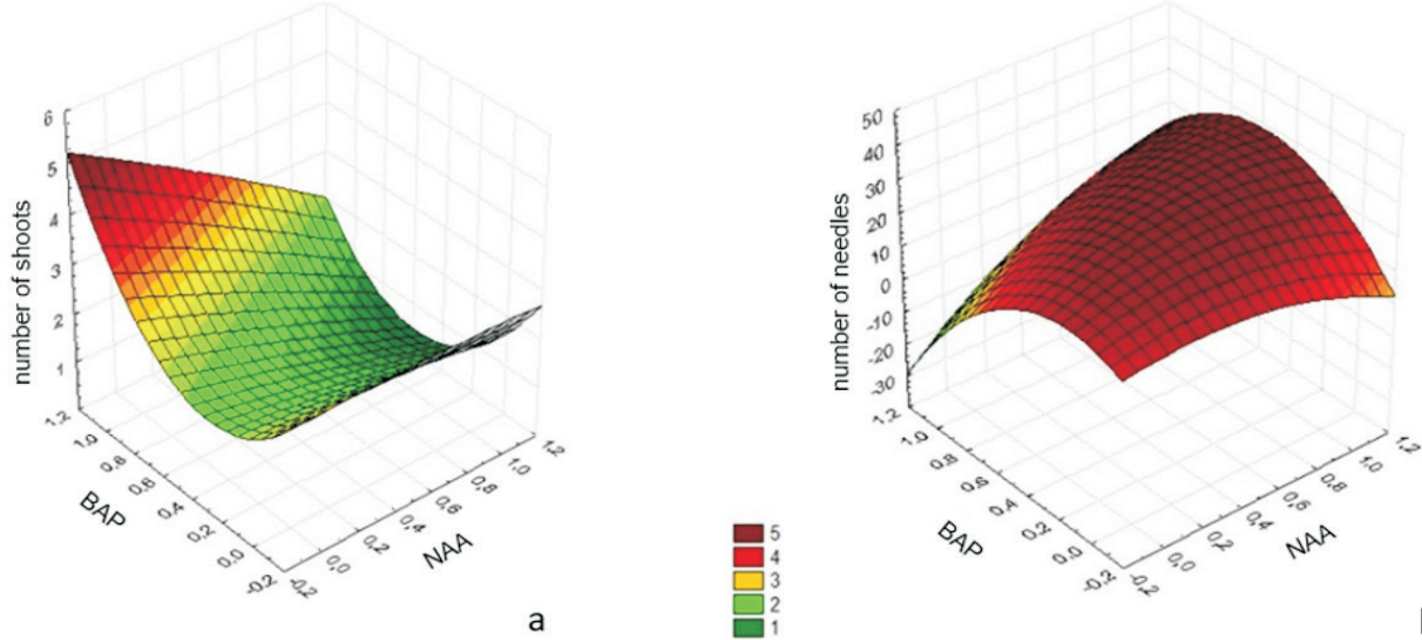

b

Figure 1.Response surface interaction chart of $\alpha$-naphtalene acetic acid (NAA) and 6-benzilaminopurine (BAP) concentrations for number of shoots (a) and number of needles (b) of explants of Sequoia sempervirens during in vitro multiplication.
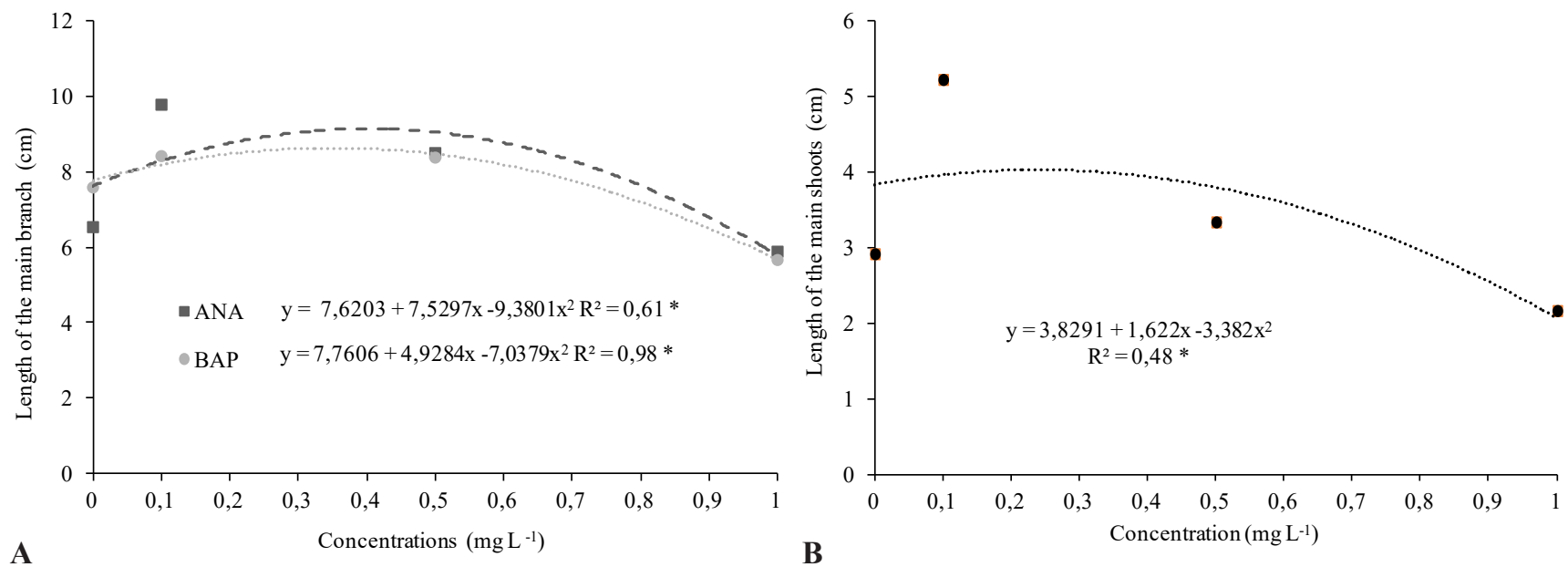

Figure 2.Mean length of the main branch (A) and of the shoots (B) of Sequoia sempervirens micro-cuttings in MS/2 culture medium supplemented with distinct concentrations of $\alpha$-naphtalene acetic acid (NAA) and 6-benzilaminopurine (BAP).

* Significant at $5 \%$ probability of error. 


\section{Effects of cytokinins}

Except for the length of the main branch of A228, all the other variables interacted $(p<0.05)$ when testing different concentration of BAP, kinetin (KIN) and 2-isopentheiladenine (2Ip) with each clone, A228 e A140 (Figures 3 and 4). The length of the main branch of explants of clone A228 was higher $(\mathrm{p}<0.05)$ when KIN $(3.50 \mathrm{~cm})$ and $2 \mathrm{iP}(3.09 \mathrm{~cm})$ were used. However explants of the same clone treated with BAP presented an average length of $2.05 \mathrm{~cm}$.

The concentrations of each cytokinin influenced the development of shoots (Figure 3a). As the highest average length of the main branch was obtained with KIN, we performed a regression analysis for increasing concentrations of this cytokinin and their effect on length. The results showed a negative quadratic trend (Figure $3 \mathrm{~b}$ ). The control and the highest concentration used ( $\left.4 \mathrm{mg} \mathrm{L}^{-1}\right)$ resulted in lower length than intermediate concentrations of KIN for clone A228. The highest length values were obtained at $0.5 \mathrm{mg} \mathrm{L}^{-1}$, with $3.54 \mathrm{~cm}$. The interaction between the cytokinin and the concentration for clone A140 is shown in Figure 3b. In this case, the highest mean length of the main branch
(3.61 cm) was obtained at $4 \mathrm{mg} \mathrm{L}^{-1}$. BAP-treated explants of clone A140 also resulted in the lowest lengths.

In general, the best performance of multiplication was achieved with KIN for the mean number of shoots for both clones (A228 and A140). Supplementing the culture medium with $1 \mathrm{mg} \mathrm{L}^{-1} \mathrm{KIN}$ was more effective for A228, while $0.5 \mathrm{mg} \mathrm{L}^{-1} \mathrm{KIN}$ implicated in better results for the micro-cuttings of A140. In average, we counted 2.6 shoots per micro-cutting of A228, while 1.15 shoots per micro-cutting were obtained of A140 (Figure $4 a)$. The superior effect of KIN was also observed on the mean length of the shoots (Figure $4 \mathrm{~b}$ ). In average, it was of $1.68 \mathrm{~cm}$ in shoots from A228 and of $1.43 \mathrm{~cm}$ from A140, at the same concentrations described for the mean number of shoots.

One prominent effect of BAP was the stimulation of calluses (Figure $4 \mathrm{c}$ ). The presence of this cytokinin, at all concentrations, promoted the development of calluses from all micro-cuttings of A228 (100\%) and almost all micro-cuttings of A140 (100\% using $\left.2.0 \mathrm{mg} \mathrm{L}^{-1}\right)$. Conversely, the supplementation with KIN implicated in low incidence of calluses from both clones at all concentrations.
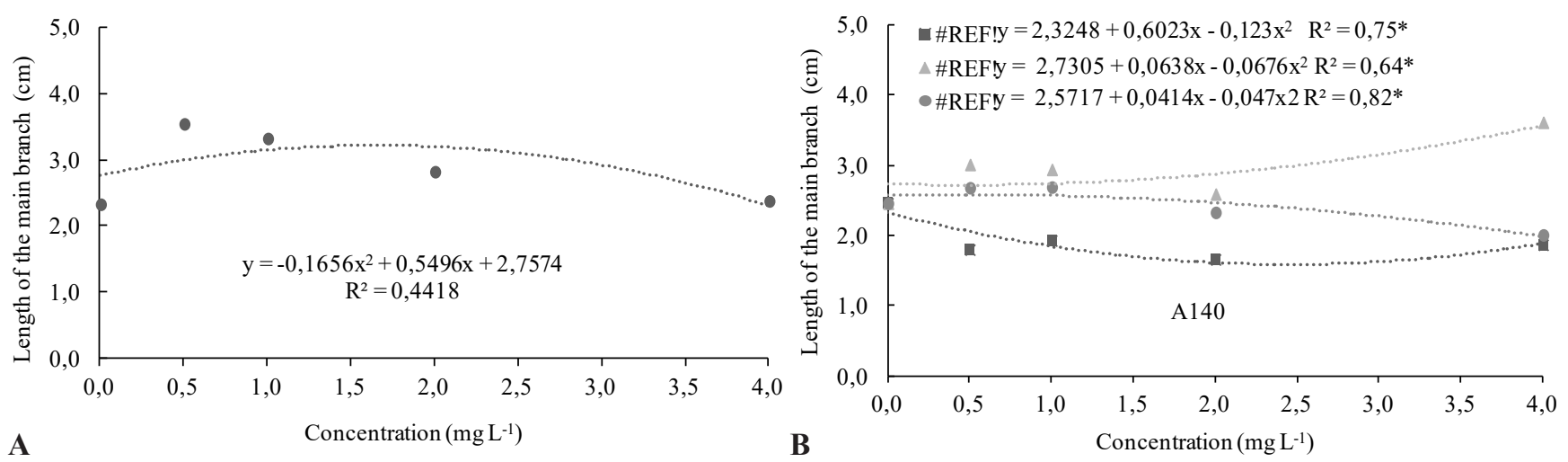

Figure 3. Average length of the main branch $(\mathrm{cm})$ of Sequoia sempervirens micro-cuttings of the clones A228 (A) and A140 (B), grown in MS/2 medium with $0 ; 0.5 ; 1.0 ; 2.0$ and $4.0 \mathrm{mg} \mathrm{L}^{-1}$ of 6-benzilaminopurine (BAP), kinetin (KIN) and 2-isopentheiladenine (2Ip). *Significant at $5 \%$. 
A

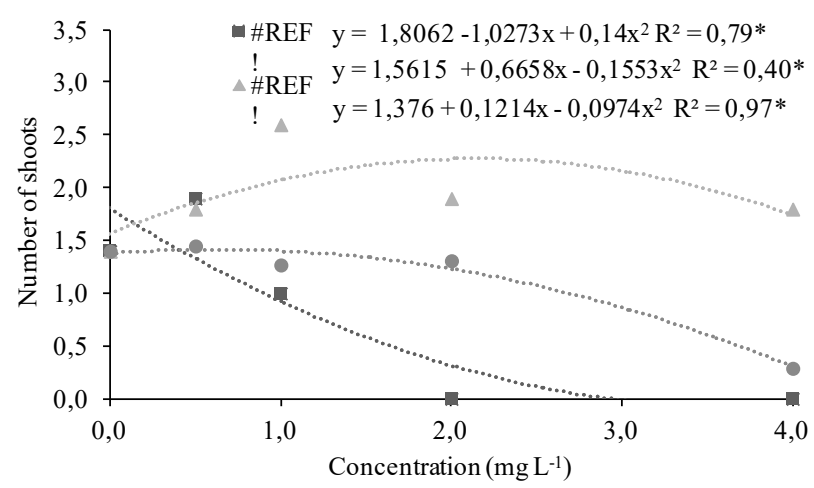

B

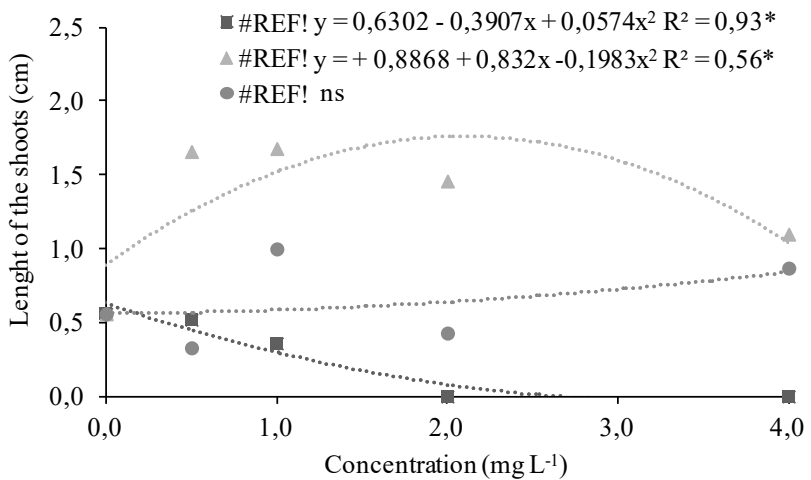

$\mathrm{C}$

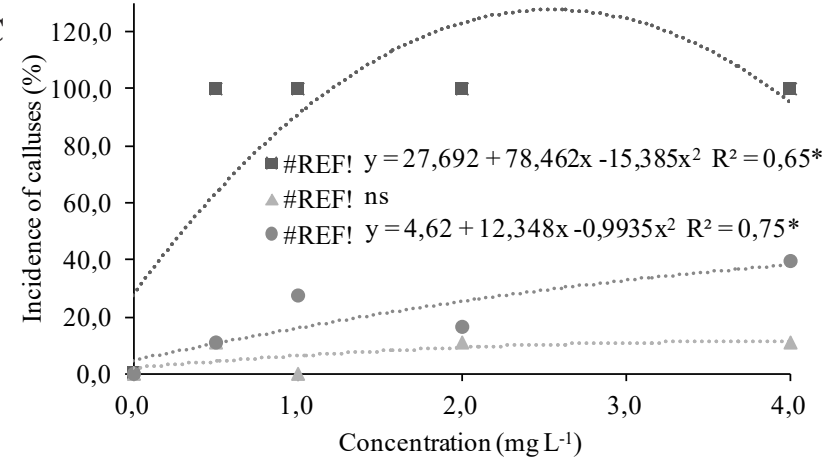

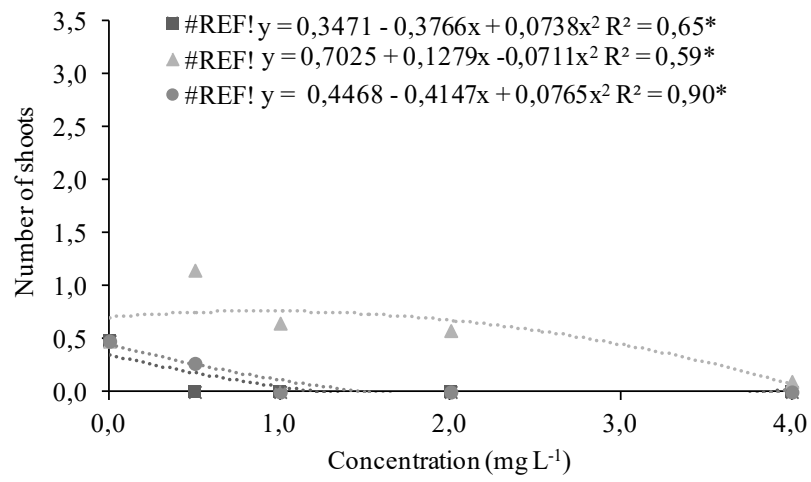
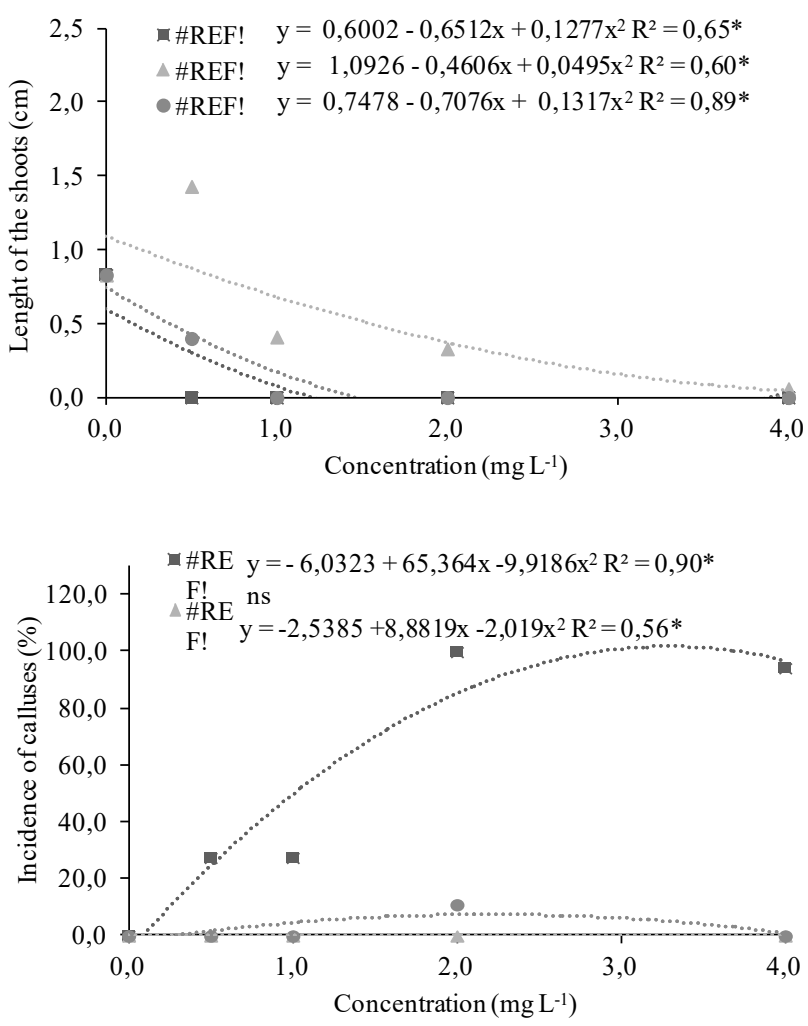

Figure 4.Effects of 6-benzilaminopurine (BAP), kinetin (KIN) and 2-isopentheiladenine (2Ip), supplemented at distinct concentrations to the MS/2 culture medium, to Sequoia sempervirens micro-cuttings of the clones A228 and A140. A) Number of shoots; B) Length of shoots; C) Induction of callogenesis (incidence of calluses).

\section{Discussion}

The combination of 6-benzilaminopurine (BAP) and $\alpha$-naphthalene acetic acid (NAA) on in vitro multiplication of Sequoia sempervirens indicated that the performance of the micro-cuttings could be improved when low concentrations of both regulators were used $\left(0,1 \mathrm{mg} \mathrm{L}{ }^{-1} \mathrm{NAA}\right.$ and $\left.0.1 \mathrm{mg} \mathrm{L}^{-1} \mathrm{BAP}\right)$. However, the best results were achieved when only KIN was supplemented to the culture medium for both clones, but at low concentrations (Figure 4). In general, auxins are involved with cell division and cell enlargement as well as the synthesis of cell wall. The role of a cytokinin is the induction of axillary buds as well as the proliferation of axillary buds by suppression of the apical dominance (Hartmann et al., 2011; Xavier et al., 2013). Both growth regulators cooperate in the multiplication of shoots, but in excessive concentration they might be toxic for the development of in vitro cultures (Wang et al., 2007; Ling et al., 2013). 
It was noteworthy that increasing the concentration of NAA had an inhibitory role in the production of shoots on both genotypes (A228 and A140). This was also observed from a study with the medicinal plant Satureja hortensis L., in which increasing concentrations of NAA diminished the number of shoots (Navroski et al., 2014). On the contrary, NAA stimulated the emission of shoots by an interaction with BAP in clones of Eucalyptus globulus Labill. The balance between cytokinin and auxin is attributed to this positive result for this species (Cordeiro et al., 2014), but it is important to consider that the interaction between such growth regulators is strongly influenced by the species and tissue type used for multiplication (Xavier et al., 2013).

Using both NAA and BAP at low concentrations resulted in improved performances $\left(0.1 \mathrm{mg} \mathrm{L}^{-1} \mathrm{NAA}\right.$ and $0.1 \mathrm{mg} \mathrm{L}^{-1}$ BAP) of shoot regeneration in $S$. sempervirens. Similar result was observed in a study with Parapiptadenia rigida (Benth), where a concentration as low as $0.5 \mathrm{mg} \mathrm{L}^{-1}$ resulted in the best multiplication performance (Kielse et al., 2009).

Although BAP could show a positive effect on in vitro multiplication of $S$. sempervirens, our second experiment demonstrated that kinetin (KIN) and 2-isopentheiladenine (2Ip) were more effective than BAP in promoting shoot multiplication. In general, reduction of the number of shoots in presence of BAP can occur, as cytokinins induce shoots via cell division, reducing size and increasing the number of cells (Santos-Serejo et al., 2006). However, it is necessary to highlight once more that the responses to such plant growth regulators depend on the species. For example, the multiplication of a medicinal plant (Scopari dulcis) showed that shoot induction was improved by a combination of both BAP and KIN (Premkumar et al., 2011). On the contrary, for cucumbers, the best results of the shoot multiplication stage were obtained when only kinetin was supplemented to the MS medium (Abu-Romman et al., 2015).

The supplementation of the culture medium with BAP in $S$. sempervirens resulted in a high rate of callogenesis (Figure 4). Callogenesis is triggered by an interaction between citokinins and auxins ( $\mathrm{Su}$ et al., 2011). More specifically, it has been shown that a specific gene (Wushell or WUS) is sufficient for inducing shoot regeneration, but its activation requires the cytokinin receptor gene AHK4, this one stimulated by auxin pretreatment of explants. Calluses tend to form depending on these interactions and also with other genes (Gordon et al., 2009). Callogenesis negatively affects adventitious rooting (Brondani et al., 2017) and might interfere with the development of further protocols aimed for seedlings formation of this species. Reduced rate of callogenesis was observed when KIN and $2 \mathrm{iP}$ were supplied to the culture medium. This was probably due to variation in the balance among endogenous plant hormones already presented by each micro-cutting and the supplied plant growth regulators.

In general, we demonstrated that kinetin implicated in the best performances for shoot multiplication in S. sempervirens. However, it was clear that the used genotypes (A228 or A140) respond differently. In general, clone A228 presented higher shoot emission than A140. Distinct performances among genotypes were also shown in direct shoot organogenesis from needles of three genotypes of S. sempervirens ( $\mathrm{Sul} \&$ Korban, 2005). Therefore, although we highlighted kinetin as the best growth regulator and indicated the most appropriate concentration for in vitro multiplication of clones A228 and A140 in S. sempervirens, such results might exhibit variation in other genotypes.

\section{Conclusions}

We provided experimental recommendation of the appropriate plant growth regulators to be used in the shoot multiplication of Sequoia sempervirens. Benzilaminopurine, above $0.5 \mathrm{mg} \mathrm{L}^{-1}$, negatively influenced shoot multiplication and implicated in high rates of callogenesis.

The use of kinetin in low concentrations provided the best performance for shoot multiplication, but with distinct recommendations according to the genotype used. In the case of our study, we recommend $1.0 \mathrm{mg} \mathrm{L}^{-1}$ KIN for clone A228 and $0.5 \mathrm{mg} \mathrm{L}^{-1} \mathrm{KIN}$ for A140.

\section{Acknowledgments}

The authors thank Coordenação de Aperfeiçoamento de Pessoal de Nível Superior - Brasil (Capes) for providing the scholarship for obtaining the Master's degree of the first author. 


\section{References}

Abu-Romman, S. et al. Kinetin is the most effective cytokinin on shoot multiplication from cucumber. Journal of Agricultural Science, v. 7, n. 10, p. 159-164, 2015. http://dx.doi.org/10.5539/ jas.v7n10p159.

Blažková, A. et al. Auxin metabolism and rooting in young and mature clones of Sequoia sempervirens. Physiologia Plantarum, v. 99, n. 1, p. 73-80, 1997. http://dx.doi.org/10.1111/j.1399-3054.1997. tb03433.x.

Brondani, G. E. et al. Mini-incubators improve the adventitious rooting performance of Corymbia and Eucalyptus microcuttings according to the environment in which they are conditioned. Anais da Academia Brasileira de Ciências, v. 90, n. 2, p. 2409-2423, 2017. http://dx.doi.org/10.1590/0001-3765201720170284.

Cordeiro, G. M. et al. Meio de cultura, BAP e ANA na multiplicação in vitro de clones de Eucalyptus globulus Labill. Scientia Forestalis, v. 42, n. 10, p. 337-344, 2014. http://dx.doi.org/10.5902/198050986626.

Ferreira, D. F. Sisvar: a computer statistical analysis system. Ciência e Agrotecnologia, v. 35, n. 6, p. 1039-1042, 2011. http://dx.doi. org/10.1590/S1413-70542011000600001.

Gordon, S. P. et al. Multiple feedback loops through cytokinin signaling control stem cell number within the Arabidopsis shoot meristem. Proceedings of the National Academy of Sciences, v. 106, n. 38, p. 16529-16534, 2009. http://dx.doi.org/10.1073/ pnas.0908122106.

Halmagyi, A. et al. The effect of low-and high-power microwave irradiation on in vitro grown Sequoia plants and their recovery after cryostorage. Journal of Biological Physics, v. 43, n. 3, p. 367-379, 2017. http://dx.doi.org/10.1007/s10867-017-9457-4.

Hartmann, H. T. et al. Plant propagation: principles and practices. 8th ed. São Paulo: Prentice-Hall, 2011. 915 p.

Huang, L. C. et al. DNA methylation and genome rearrangement characteristics of phase change in cultured shoots of Sequoia sempervirens. Physiologia Plantarum, v. 145, n. 2, p. 360-368, 2012. http://dx.doi.org/10.1111/j.1399-3054.2012.01606.x.

Kielse, P. et al. Regeneração in vitro de Parapiptadenia rigida (Bentham) Brenan. Ciência Rural, v. 39, n. 4, p. 1098-1104, 2009. http://dx.doi.org/10.1590/S0103-84782009005000046.

Ling, A. P. K. et al. Comparative effects of plant growth regulators on leaf and stem explants of Labisia pumila var. alata. Journal of Zhejiang University Science B, v. 14, n. 7, p. 621-631, 2013. http:// dx.doi.org/10.1631/jzus.B1200135.

Liu, C. et al. Shoot regeneration and somatic embryogenesis from needles of redwood (Sequoia sempervirens (D. Don.) Endl.). Plant Cell Reports, v. 25, n. 7, p. 621-628, 2006. http://dx.doi.org/10.1007/ s00299-006-0120-y.
Murashige, T. \& Skoog, F. A revised medium for rapid growth and bioassays with tobacco tissue cultures. Physiologia Plantarum, v. 15, p. 473-497, 1962. http://dx.doi.org/10.1111/j.1399-3054.1962. tb08052.x.

Navroski, M. C. et al. In vitro multiplication of apical shoot segments of Summer Savory (Satureja hortensis L.). Revista Brasileira de Plantas Medicinais, v. 16, n. 1, p. 117-121, 2014. http://dx.doi. org/10.1590/S1516-05722014000100017.

Navroski, M. C. et al. Resgate e propagação vegetativa de Sequoia sempervirens. Floresta, v. 45, n. 2, p. 383-392, 2015. http://dx.doi. org/10.5380/rf.v45i2.35407.

Olson, D. F. et al. Sequoia sempervirens (D. Don) Endl. redwoods. In: Burns, R. M. \& Honkala, B. H. Silvics of North America: volume 1: conifers. Washington, DC: US Department of Agriculture, Agricultural Handbook, 1990. p. 541-551.

Ozudogru, E. A. et al. Cryopreservation of redwood (Sequoia sempervirens (D. Don.) Endl.) in vitro buds using vitrification-based techniques. CryoLetters, v. 32, n. 2, p. 99-110, 2011.

Premkumar, G. et al. Cytokinin induced shoot regeneration and flowering of Scoparia dulcis L.(Scrophulariaceae)-an ethnomedicinal herb. Asian Pacific Journal of Tropical Biomedicine, v. 1, n. 3, p. 169-172, 2011. http://dx.doi.org/10.1016/S2221-1691(11)60020-8.

Rocha, P. S. G. et al. Multiplicação e alongamento in vitro do portaenxerto de Prunus. Bioscience Journal, v. 25, n. 1, p. 69-74, 2009.

Santos-Serejo, J. A. et al. Meios nutritivos para micropropagação de plantas. In: Souza, A. S. \& Junghans, T. G. Introdução à micropropagação de plantas. Cruz das Almas: Embrapa Mandioca e Fruticultura Tropical, 2006. p. 80-98.

Statistica 6.0: Statistica is a data analysis and visualization program. [S.1.]: Informer Technologies, 2019. Disponível em: $<$ http://statistica. software.informer.com/6.0/>. Acesso em: 5 abr. 2019.

Sul, I. W. \& Korban, S. S. Direct shoot organogenesis from needles of three genotypes of Sequoia sempervirens. Plant Cell, Tissue and Organ Culture, v. 80, n. 3, p. 353-358, 2005. https://doi.org/10.1007/ s11240-004-1365-1

$\mathrm{Su}, \mathrm{Y} . \mathrm{H}$. et al. Auxin-cytokinin interaction regulates meristem development. Molecular Plant, v. 4, n. 4, p. 616-625, 2011. http:// dx.doi.org/10.1093/mp/ssr007.

Xavier, A. et al. Silvicultura clonal: princípios e técnicas. Viçosa, MG: Ed da UFV, 2013. 272 p.

Wang, B. et al. An efficient adventitious shoot regeneration system for ramie (Boehmeria nivea Gaud) using thidiazuron. Botanical Studies, v. 48, n. 2, p. 173-180, 2007. 